\title{
Evaluation of the environmental impact of two types of food in intensive farming of rainbow trout fry (Onchoryncus mykiss. Walbaum, 1792).
}

El Hassan abba ( $\square$ abbaelhassan@gmail.com ) university of sultan moulay sliman beni mellal https://orcid.org/0000-0001-9901-6034

Oumaima Dahak

Universite Moulay Ismail. Meknès

\section{Tarik Ainane}

University of Sultan Moulay Slimane. Beni Mellal

Adnane El Yaacoubi

University of Sultan Moulay Slimane. Beni Mellal

\section{Research}

Keywords: Fish farming, environmental impact, Water quality, nitrogen, phosphorus, intensive breeding

Posted Date: May 5th, 2020

DOI: https://doi.org/10.21203/rs.3.rs-25949/v1

License: (a) (i) This work is licensed under a Creative Commons Attribution 4.0 International License. Read Full License 


\section{Abstract}

The environmental impact of two types of food distributed during the first phase of intensive breeding of rainbow trout (Oncorhynchus mykiss) fry at the station of the National Center for Hydrobiology and Pisciculture constitutes the main objective of this study. the method used for the evaluation of the impact of these two foods is the mass balance method based on the calculation of the quantities of nitrogen and phosphorus excreted according to the quantities of food ingested and the composition of the carcasses. The results obtained show that the weight growth of fry and the rate of nitrogen and phosphorus rejection during the experimental period are very different and vary depending on the type of food received.

\section{1- Introduction}

Food requirements for animal protein continue to increase due to global population growth. Fish farming, which constitutes the main branch of aquaculture, can contribute on the one hand to the increased demand for protein, on the other hand, to the reduction of the impact on the natural resources of the marine environment. The last two decades have seen significant fish production; in 2014, the contribution of fish farming to fish intended for human consumption exceeded that of the fishing sector for the first time [1]. This increase and intensification of world production, especially in freshwater environments, could have some impacts on the environment. Typical changes in the quality of water after its use for fish farming, among others the decrease in oxygen, the variation of the Hydrogen potential $(\mathrm{pH})$, the increase in suspended matter [2] and especially phosphorus and nitrogen inputs.

These last elements constitute potential sources of food for phytoplankton and consequently the increase in the productivity of the aquatic ecosystem causing the phenomenon of eutrophication which is directly associated with discharges of solids and metabolic waste and therefore depends on the quality and the biological valorization of food $[3,4,5,6]$.

The main objective of this study is to assess the impact of fish discharges from the rainbow trout (Oncorhynchus mykiss, Walbaum, 1792) fry fed two types of food at the National Center fish farm. Hydrobiology and fish farming (Morocco). In order to reach our objective, we followed the weight growth which varies according to the composition of the food, their digestibility and the rate of food conversion. These various parameters largely condition the level of discards from fish farming [7], especially for phosphorus and nitrogen which play a crucial role in the phenomenon of eutrophication which leads to the imbalance of species aquatic. [8]. In addition, the presence of nitrogenous forms (ammonia nitrogen) in water can cause poisoning in fish farming [9].

\section{2- Methods And Material \\ 2-1 Description of the experimental station}


The experiment was carried out in an incubation and nursery room at the National Center of Hydrobilogical and Pisciculture (NCHP) salmon aquaculture station in specific rectangular troughs in parallel with a suitable volume of the order of $0.16 \mathrm{~m} 3$ and circular tanks. The water supply was made by taps with a flow rate of $0.97 \mathrm{~m} 3 / \mathrm{h}$ whose origin is a source. The troughs are equipped with a ventilation system by diffuser allowing the concentration of dissolved oxygen to be kept close to saturation if necessary. During the experimental period (nursery phase), physicochemical parameters ( $\mathrm{pH}$, dissolved oxygen and temperature) were monitored by calibrated devices of the Oreon type.

\section{2-2 Biological material and food ration}

After hatching, 2000 fry from the same batch of eggs were distributed randomly and equally in 4 troughs (A1, A2, A3 and A4). The fry of the different troughs are subject to the same nursery conditions. Each week, and in order to determine the food ration for all the biomass according to the rationing table provided by the manufacturer, the weight of 30 fish per trough was determined after anesthesia. The fry in groups 1 and 2 are fed on food $A$ and those in groups 3 and 4 are fed on food B (Table 1). The quantity of food was distributed in four meals from 9 a.m. to 5 p.m. during the whole experimental period.

Table 1

Composition of two foods tested

\begin{tabular}{|lll|}
\hline Components & Food A & Food B \\
\hline Crud protein & $47 \%$ & $48 \%$ \\
\hline Crud fat & $18 \%$ & $22 \%$ \\
\hline Crud cellulose & $1,33 \%$ & $2,2 \%$ \\
\hline Crud ash & $8,75 \%$ & $8,3 \%$ \\
\hline Total phosphorus & $1,32 \%$ & $0,8 \%$ \\
\hline Calcium & $0,80 \%$ & -- \\
\hline Sodium & $0,62 \%$ & -- \\
\hline
\end{tabular}

The food ration is determined according to the biomass of the different trout by the following formula: $\mathrm{TN}=$ (Biomass $\times$ Feeding rate) $/ 100[10]$.

\section{2-3 Zootechnical parameters}

Monitoring of weight growth is an important parameter in species biology regardless of the type of breeding. The evaluation of the quality of a feed in an intensive fish farm and therefore the rate of phosphorus and nitrogen rejection and their impact on the environment can be determined from the combination of several parameters including the weight gain during the experimentation period. According to [11], the weight gain is calculated as follows: G.P\% $=\left(P_{m f}(g)-P_{m i}(g)\right)$ : 
With, $P_{m f}=$ Average weight at the end of the breeding period and $P_{m i}=$ Initial average weight at the start of the breeding.

In addition to the weight growth parameter, we carried out the survival rate (SR \%) of the fry during the nursery period according to the following formula:

SR $(\%)=($ Final number of fish $\times 100) /$ Initial number of fish

2-4 Determination of the quantity of phosphorus and nitrogen discharge.

To grow, organisms need fundamental nutritious food, among which phosphorus $(P)$ and nitrogen $(N)$. Plants assimilate dissolved forms of $\mathrm{P}$ and $\mathrm{N}$ in water (ortho phosphates and nitrates) in synergy with other nutrients [4].

In contrast, intensively farmed fish receive these two elements in their diet. $\mathrm{P}$ and $\mathrm{N}$ are involved in several metabolic processes in fish. Unfortunately, the quantities provided by food are not completely ingested and digested [12], and therefore they are released into the aquatic environment in different forms.

The quantity of $\mathrm{P}$ and $\mathrm{N}$ discharges into the aquatic environment closely depends on the quantity of protein in the fish diet and on the Conversion Index $(\mathrm{Cl})$ which quantifies the performance of fish farming [13]. For rainbow trout, 40 to $60 \%$ of $\mathrm{N}$ contained in the proteins received is excreted in dissolved form through the urine and the gills, 10 to $25 \%$ is found in the fecal matter, only the remaining $35 \%$ are used in fish growth.

For $P$, the retention rate is between $20 \%$ and $55 \%[14,15,16,17]$. These quantities vary depending on the food, its digestibility rate and environmental conditions. According to these different authors, for rainbow trout, 60 to $80 \%$ of the phosphorus is rejected in particulate form (the phosphorus not ingested is eliminated by the faeces), and between 40 to $20 \%$ is eliminated in dissolved form through the urine and gills. On average, only $40 \%$ of phosphorus in food proteins is used by fish for growth. With respect to environmental impact, the dissolved part of phosphorus and nitrogen is the major problem compared to the solid part that undergoes treatments that improve over time through decanter or filtration systems [16, 18]. In our case, the removal of the solid part was carried out by the siphoning technique during the whole period of breeding. The evaluation of the quantity of phosphorus and nitrogen discharges into the environmental medium in a fish farm varies according to several methods. The models developed for the assessment of fish discharges present different results $[14,19]$. In this study, we used mass balances to calculate nitrogen and phosphorus excretion based on the amounts ingested and the composition of the carcasses $[20,21,22]$. This nutritional method was developed to overcome the heaviness, costs and biases caused by other methods. The quantities of nitrogen and phosphorus released to water were evaluated as follows.

For nitrogen releases : $\mathbf{k g ~ N}=(\mathbf{A} \times \mathbf{C ~ N a})-(\operatorname{Pr} \times \mathbf{C N} p)$, with, A : Quantity of food distributed $(\mathrm{kg}), \mathrm{C} \mathrm{Na}$ : Percentage by weight of nitrogen in the food (\% protein +6.25$)$, Pr: Weight gain achieved by the fish $(\mathrm{kg})$, 
and C Np: Percentage by weight of nitrogen in the fish (3\%).

For phosphorus discharges: $\mathbf{k g} \mathrm{P}=(\mathrm{A} \times \mathrm{C} \mathrm{Pa})$ - ( $\mathrm{Pr} \times \mathrm{C} \mathrm{Pp})$ with, A: Quantity of food distributed $(\mathrm{kg}), \mathrm{C} \mathrm{Pa}$ : Percentage by weight of phosphorus in the food, Pr: Weight gain made by fish $(\mathrm{kg})$ and CPp: Percentage by weight of phosphorus in fish (0.4\%).

\section{3- Results And Discussion}

\section{3-1Physicichemical parameters of water}

Monitoring of basic physico-chemical parameters, temperature $\left({ }^{\circ} \mathrm{C}\right)$, dissolved oxygen $(\mathrm{mg} / \mathrm{L})$ and hydrogen potential $(\mathrm{pH})$ during the experimental period shows that the averages of the determined parameters (Table 2) are in accordance the needs of the nursery stage in salmonids [23]. The results obtained [24] corroborate those obtained by [25].

Table 2

Average of physicochemical parameters of water

\begin{tabular}{|llll|}
\hline Parameters & $\mathbf{0 2}$ dissolved $(\mathrm{mg} / \mathrm{L})$ & Temperature $\left({ }^{\circ} \mathrm{C}\right)$ & Potential Hydrogen \\
\hline Average & 6,9 & 14 & 7 \\
\hline
\end{tabular}

\section{2-3 Zootechnical parameters}

The study of the zootechnical parameters during the test period per week $(\mathrm{S} 1, \mathrm{~S} 2, \ldots \mathrm{S} 13)$ shows a big difference between the final weight and the weight gain of each fry according to the type of food received. Table 2 shows the average of the results $(\mathrm{G} 1+\mathrm{G} 2$ and $\mathrm{G} 3+\mathrm{G} 4)$ of the weight growth of the fry according to the composition of the food tested. The fry fed with food $A$, show a significant growth, their average weight passed from 2,58 $\mathrm{g}$ (t0: first day of the experiment) to an average weight of $50 \mathrm{~g}$ at the thirteenth week (S13) of breeding against only $9.28 \mathrm{~g}$ for fry fed on food B. The average weight gain (g) and the survival rate (\%) are respectively $47.42 \mathrm{~g}$ and $99.8 \%$ for the first batch of fry (G1 + G2) against only $6.7 \mathrm{~g}$ and $25.3 \%$ for the batch (G3 + G4) (Table 3, 4). 
Table 3

Average weight growth $(\mathrm{Wa})$ of fry according to the food tested

\begin{tabular}{|llll|}
\hline Breeding Weeks & $\begin{array}{l}\text { W (g) fry } \\
(\mathbf{G} 1+\mathbf{G}) / 2\end{array}$ & $\begin{array}{l}\text { W (g) fry } \\
(\mathbf{G} 3+\mathbf{G}) / 2\end{array}$ & Standard deviation \\
\hline T0 & 2,58 & 2,58 & 0 \\
\hline S1 & 3,605 & 3,425 & 0,12727922 \\
\hline S2 & 4,935 & 5,025 & 0,06363961 \\
\hline S3 & 6,845 & 6,315 & 0,37476659 \\
\hline S4 & 8,5 & 6,695 & 1,27632774 \\
\hline S5 & 12,235 & 7,425 & 3,40118362 \\
\hline S6 & 14,22 & 7,185 & 4,97449621 \\
\hline S7 & 15,195 & 8,385 & 4,81539718 \\
\hline S8 & 22,04 & 7,41 & 10,3449722 \\
\hline S9 & 26,545 & 7,43 & 13,5163461 \\
\hline S10 & 32,195 & 8,11 & 17,0306668 \\
\hline S11 & 35,8 & 8,28 & 19,4595786 \\
\hline S12 & 41 & 9,555 & 22,2349727 \\
\hline S13 & 50 & 9,28 & 28,7933881 \\
\hline
\end{tabular}

Table 4

Average of the zootechnical parameters of the fry according to the food tested

\begin{tabular}{|lll|}
\hline Zootechnical parameters & Food tested & Standard deviation \\
\hline & A B & \\
\hline Initial fry weight (g) & $2,582,58$ & 0 \\
\hline Final fry weight (g) & 509,28 & 28,7933881 \\
\hline Average weight (g) & $47,426,7$ & 28,7933881 \\
\hline Survival rates\% & $99,825,3 \%$ & 52,6794552 \\
\hline
\end{tabular}

3-3 Nitrogen and phosphorus discharges from tested foods

The quantities of nitrogen and phosphorus released to water were evaluated according to the following formulas: Nitrogen releases: $k g N=(A \times C N a)-(\operatorname{Pr} \times C N p)$, Phosphorus releases: $k g P=(A \times C P a)-(\operatorname{Pr} \times$ C Pp). 
The calculation of the quantity of feed distributed per week is determined according to the total biomass of the fry in the troughs and according to the water temperature $\left(14^{\circ} \mathrm{C}\right)$ and the ration table.

The biomass of the fry at time t0 and that of the fry at the end of the experiment S13 on the one hand, and the quantity of feed distributed during the whole nursery period on the other hand (Table 5 ) make it possible to evaluate the pollution rate generated by each food and therefore its impact on the environment.

Table 5

Average biomass of fry per week and different amounts of food ( $A$ and $B$ ) distributed during the experiment

\begin{tabular}{|lllll|}
\hline $\begin{array}{l}\text { Breeding } \\
\text { weeks }\end{array}$ & $\begin{array}{l}\text { Biomass } \\
\text { (G1 }+ \\
\text { G2/2)/ } \\
\text { Week }\end{array}$ & $\begin{array}{l}\text { Quantity of food A } \\
\text { distributed / } \\
\text { Week }\end{array}$ & $\begin{array}{l}\text { Biomass } \\
\text { (G3+ }\end{array}$ & $\begin{array}{l}\text { Quantity of food distributed B } \\
\text { /week }\end{array}$ \\
\hline T0 & 2,58 & 0,116 & week & \\
\hline S1 & 3,605 & 0,162 & 2,58 & 0,121 \\
\hline S2 & 4,935 & 0,222 & 3,425 & 0,154 \\
\hline S3 & 6,845 & 0,238 & 5,025 & 0,226 \\
\hline S4 & 8,5 & 0,297 & 6,315 & 0,221 \\
\hline S5 & 12,235 & 0,318 & 6,695 & 0,234 \\
\hline S6 & 14,22 & 0,370 & 7,425 & 0,260 \\
\hline S7 & 15,195 & 0,395 & 7,185 & 0,252 \\
\hline S8 & 22,04 & 0,573 & 8,385 & 0,293 \\
\hline S9 & 26,545 & 0,557 & 7,41 & 0,260 \\
\hline S10 & 32,195 & 0,676 & 7,43 & 0,260 \\
\hline S11 & 35,8 & 0,739 & 8,11 & 0,284 \\
\hline S12 & 41 & 0,738 & 8,28 & 0,290 \\
\hline S13 & 50 & 5,40 & 9,555 & 0,335 \\
\hline Total & $50 \mathrm{Kg}$ & $5,4 \mathrm{Kg}$ & 9,28 & 3,184 \\
\hline
\end{tabular}


Table 6

Nitrogen and Phosphorus discharges of the two foods during the nursery period

\begin{tabular}{|lll|}
\hline & Nitrogen discharges: $\mathrm{Kg} /$ 107days & Phosphorus discharges: Kg/107days \\
\hline Food A & $0,254 \mathrm{Kg}$ & $0,097 \mathrm{Kg}$ \\
\hline Food B & $0,034 \mathrm{Kg}$ & $0,026 \mathrm{~kg}$ \\
\hline
\end{tabular}

The amount of nitrogen and phosphorus generated by the two foods tested are listed in Table 6.

During the nursery period, the total biomass obtained is $50 \mathrm{~kg}$ for the fry fed by food $\mathrm{A}$ and $9.3 \mathrm{Kg}$ for the fry fed by food B. The quantity of feed distributed is respectively $5,4 \mathrm{~kg}$ for the first batch of fry and $3.2 \mathrm{Kg}$ for the second batch. In terms of zootechnical parameters, which are the basis in fish farming, the results clearly show the efficiency of food A compared to that of food B. This big difference is explained in particular by the rate of survival which is $99.8 \%$ for the fry fed on food $A$, against only $25.3 \%$ for the fry fed on food B.

The quantities of nitrogen and phosphorus released into the natural environment during the nursery period are respectively around $0.254 \mathrm{~kg}$ of $\mathrm{N}$ and $0.097 \mathrm{~kg}$ of $\mathrm{P}$ for food $\mathrm{A}$; and $0.034 \mathrm{~kg}$ of N and $0.026 \mathrm{~kg}$ of $\mathrm{P}$ for food $\mathrm{B}$. These results clearly show that food $\mathrm{B}$ has more negative impact on the environment compared to food A since, the amount of 'food B $(3.2 \mathrm{Kg})$ distributed generates more nitrogen released into the natural environment $(1.5 \mathrm{KgN})$ than the amount of nitrogen $(1.4 \mathrm{Kg})$ eliminated by the use of $5.4 \mathrm{Kg}$ of food $\mathrm{A}$. These results can be explained by the fact that the digestibility of food $B$ is not important, this corroborates with the weight gain which is very low for food $B$ compared to food $A$. For phosphorus, the impact on the natural environment of food $A$ is of the order of $0.12 \mathrm{~kg} / 107 \mathrm{~d}$ for a quantity of food distributed equal to $5.4 \mathrm{~kg}$, for food B, the quantity of $P$ released is $0.015 \mathrm{Kg} / 107 \mathrm{~J} \mathrm{for}$ $3.2 \mathrm{Kg}$ of food distributed. This difference in results can be explained on the one hand, by the quantity of food distributed (5.4 and 3.2Kg / 107J), on the other hand, the quantity of phosphorus contained in the two foods which is respectively $1,32 \% \mathrm{P}$ for food $\mathrm{A}$, against only $0.8 \%$ for food $\mathrm{B}$.

\section{Conclusion}

Foods used in the field of breeding in general, and in fish farming mainly, must meet some criteria. On the one hand, the yield, the quality of the fish pulp, availability at a lower price and the welfare of the fish and on the other hand respect for the environment. By way of this experimental study, the main objective of which is the evaluation of the impact of these two foods on water resources, it can be concluded that food $A$ meets the needs of the farmer vis-à-vis the yield since the survival rate of fry is close to $100 \%$ with a biomass which far exceeds that of food B. In terms of impact on the environment, food A, shows good results for discards in nitrogen since the quantity eliminated is not significant compared to the quantity of food distributed. For phosphorus, the impact of the two foods on water resources is high for food A.

\section{Declarations}


Availability of data and materials

The data used to support the findings of this study are available from the corresponding author upon request

\section{Competing interests}

The authors declare they have no competing interests

\section{Funding}

This research received no specific grant from any funding agency

\section{Authors' contributions}

Conceptualization, A.E.H.; Methodology, A.E.H., and D.O.; Supervision, A.R.; Writing-original draft, A.E.H., and D.O. Writing-review \& editing, A.E.H., D.O., and E.Y.A.

\section{Acknowledgments}

This work is part of master thesis Dahak Oumaima.The authors thank the members of the National Center of Hydrobiology and Pisciculture very much for their support during the experiment and internship carried out at the level of their structure.

\section{References}

1. FAO. La situation mondiale des pêches et de l'aquaculture 2016. Contribuer à la sécurité alimentaire et à la nutrition de tous. Rome. 224 pages.

2. Lemarié G. Les rejets particulaires des élevages de poissons: caractéristiques et méthodes d'élimination. La pisciculture française. 1997;127:2-11.

3. UMA Engineering Ltd. Waste water treatment in aquaculture facilities. Rapport déposé à Ministry of Environment, Water Reasources Branch, Toronto, Ontario. 1988,61 p. + 3 annexes.

4. Guy O. Les rejets des stations piscicoles et leurs impacts environnementaux. Ministère de I'Agriculture, des Pêcheries et de l'Alimentation. Quebec. Canada. 1999.

5. Papatryphon EJ, Petit SJ, Kaushik HMG, Werf VD. Environmental impact assessment of salmonids feeds using Life Cycle Assessment. Ambio. 2004;33:316-23.

6. Mungkung R, Aubina. J, Prihadid TH, Slembroucke J, Hayo MG. Werfab VD, Legendree M. Life Cycle Assessment for environmentally sustainable aquaculture management: a case study of combined aquaculture systems for carp and tilapia. Journal of Cleaner Production Volume. October 2013;57:249-56. 15 .

7. Ackefors $\mathrm{H}$, et Enell $\mathrm{M}$. The release of nutrients and organic matter from aquaculture systems in Nordic countries. J Appl Ichthyol. 1994;10(1):225-41. 19 )28-35. 
8. Grouz NA. Eutrophisation et dynamique du phosphore et de l'azote en Seine. Un nouveau contexte suite à l'amélioration du traitement des eaux usées. Thèse de doctorat en Biogéochimie Université Pierre et Marie Curie- UMR METIS. 2015.

9. Person -L, Ruyet J, Bœuf G. L'azote Ammoniacal, un toxique potentiel en élevage de poissons: Le cas du Turbot. Bull Fr Pêche Piscic. 1998;350-351:393-412.

10. Leitriz E, Lewis RC. Trout and Salmon culture (Hatchery methods), California Fish Buletin $\mathrm{N}^{\circ} 164$. Janvier: University of California; 1980. p. 109.

11. Goubier J. Biogéographie. Biométrie et biologie du sandre Lucioperca Lucioperca. L. 1975.

12. Prasuhn V, Flisch R. Le phosphore dans l'agriculture. Schriftenreihe der FAL. 57. 2005.

13. Aubin JE, Papatryphon HMG, Werf VD. Assessment of the environmental impact of carnivorous finfish production systems using Life Cycle Assessment. J Cleaner Production 2009; 17 : 354 - 61.

14. Dosdat A. L'excrétion chez les poissons téléostéens: II - Le phosphore. La pisciculture française, no. 1992b; 109: 18-29.

15. Cho CY, Hynes JD, Wood KR, Yoshida HK. Quantitation of fish culture wastes by biological (nutritional) and chemical (limnological) methods; the development of high nutrient dense (HND) diets. DANS: C.B. Cowey et C.Y. Cho, editors. Nutritional Strategies and Aquaculture Waste. Proceedings of the First International Symposium on Nutritional Strategies in Management of Aquaculture Waste. University of Guelph, Guelph, Ontario. 1991; p. 37-50.

16. Dosdat A, Servais R, Metailler R, Huelvan C, Desbruyeres E. Comparison of nitrogenous losses in five teleost fish species. Aquaculture. 1996;141:107-27.

17. Azevedo PA, Cho CY, Leeson S, Bureau DP. Effects of feeding level and water temperature on growth, nutrient and energy utilization and waste outputs of rainbow trout (Oncorhynchus mykiss). Aquatic Living Ressources. 1998;11(4):227238.

18. Aubin J. Evaluation des rejets de pisciculture par l'utilisation des bilans de masse. Principes et application en pisciculture de truite et de turbot. Premières journées recherche filière piscicole. 3-4 Juillet 2007. Paris.

19. Dominique $\mathrm{PB}$, Katheline $\mathrm{H}$. Towards effective nutritional management of waste outputs in aquaculture, with particular reference to salmonid aquaculture. Aquac Res. 2010;41:777-92.

20. Ackefors. and Enell. Discharge of nutrients from Swedish fish farming to adjacent sea areas. AMBIO. 1990.

21. Boujard T, Vallée F, Vachot C. Évaluation des rejets d'origine nutritionnelle de truiticultures par la méthode des bilans Comparaison avec les flux sortants. 2004.

22. Papatryphon E, Petit J, Hayo V, Kaushik SJ, Claver K. Nutrient balance modelling as a tool for environmental management in aquaculture: The case of trout farming in France. J Environ Manage. 2005;35:161-74.

23. Morin R. «Qualité de l'eau requise pour l'élevage des salmonidés ». Document d'information DADD14. Ministère de l'Agriculture, des Pêcheries et de l'Alimentation. 2012. 25 p. 
24. Dahak O, Abba EH, Rguibi Idrissi H, Aba M, Mbarki M, Barazouk O, Adel N. Comparative Study of Zootechnical Performances and Survival Rates in Rainbow Trout Subjected to Two Foods with Different Formulation. International Journal of Environment, Agriculture and Biotechnology (IJEAB). Vol - 2, Issue-4, July-Aug- 2017.

25. Abba EH. Etude Ecologique et biologique de la truite commune (salmo trutta macrostigma, Dumeril, 1858) de l'oued Sidi Rachid (Ifrane-Maroc). Thèse de Doctorat. Spécialité: Sciences de l'environnement. Université Ibn Tofail Faculté des Sciences. Kenitra. Maroc. 2011. 